\title{
Aleyrodidae in three forest fragments in the state of Rio de Janeiro, Brazil
}

\section{Aleyrodidae em três fragmentos florestais no estado do Rio de Janeiro}

\author{
Thiago Dias Trindade ${ }^{\text {* }}$ (D), Henrique Trevisan ${ }^{1}$ (D), Acácio Geraldo de Carvalho' \\ | | | | | | | | | | | | | | | | | | | | | | | | | | | | | | | | | | | | | | | | | | | | | | | | | | | | | | | | | | | | | | | | | | | | | | | | | | | | | | | | | | | | | | | | | | | | | | | | | | | | | | | | | | | | | | | | | | | | | | | | | | | | | | | | | | | | | | | | | | | | | | | | | | | | | | | | | | | | | | | | | | | | | | | | | | | | | | | | | | | | | | | | | | | | | | | | | | | | | |
}

\begin{abstract}
Studies that analyze the occurrence of whiteflies in forest environments are virtually non-existent, which is not justifiable given the ecological and agronomic importance of this insect group. The study aimed to evaluate the occurrence of Aleyrodidae collected from May/2013 to May/2014 in three Atlantic forest fragments in state of Rio de Janeiro, Brazil. Of all, 1,212 puparia were collected, and five genera and seven species of whiteflies occurring in nine hosts were identified. Aleuropleurocelus cecropiae was the only aleyrodid registered simultaneously occurring in Cecropia hololeuca in the three environments, with lower records in the two fragments considered as less anthropized. For the first time, Aleurothrixus floccosus was registered on Handroanthus ochraceus and Mangifera indica. In addition, it was observed the first register of Bemisia tabaci on Commelina benghalensis and Caesalpinia pluviosa. Minutaleyrodes minuta on Syzygium cumini was also the register of a new occurrence.
\end{abstract}

KEYWORDS: conservation; forestry; forest protection.
RESUMO: São praticamente inexistentes os trabalhos que analisam a ocorrência de moscas-brancas em ambientes florestais, o que não é justificável, em vista da importância ecológica e agronômica desse grupo de insetos. Objetivou-se avaliar a ocorrência de Aleyrodidae em três fragmentos de Mata Atlântica no estado do Rio de Janeiro, no período entre maio/2013 e maio/2014. Propóe-se chave taxonômica para cinco gêneros. Coletaram-se 1.212 pupários e identificaram-se cinco gêneros e sete espécies de moscas-brancas ocorrendo em nove hospedeiros. Aleuropleurocelus cecropiae foi o único aleirodídeo registrado simultaneamente, ocorrendo em Cecropia hololeuca, nos três ambientes avaliados, com registros inferiores nos dois fragmentos considerados menos antropizados. Ainda, registrou-se pela primeira vez Aleurothrixus floccosus em Handroanthus ochraceus e em Mangifera indica. Também se procedeu ao primeiro registro de Bemisia tabaci em Commelina benghalensis e Caesalpinia pluviosa. Minutaleyrodes minuta sobre Syzygium cumini é, igualmente, o registro de uma nova ocorrência.

PALAVRAS-CHAVE: conservação; área florestal; proteção florestal. 


\section{INTRODUCTION}

The aleyrodids are classified in the suborder Sternorrhyncha and characterized by the existence of an intestinal chamber responsible for facilitating the absorption and concentrating the nutrients to be utilized in the insect's metabolism. The filter chamber captures the excess of sap sucked at the beginning of the digestive tract and directs it to its end. GALLO et al. (2002) report that the surplus of sap is eliminated in the form of droplets, which can be used as a substrate for the development of fungi of the genus Capnodium sp. and as food for ants (Hymenoptera).

The aleyrodid reproduction generally occurs in a sexed way with oviparity, but it can be verified the existence of parthenogenesis of the arrhenotokous type, as mentioned by COSTA LIMA (1942), GALLO et al. (2002), GULLAN; CRANSTON (2007). According to BYRNE; BELLOWS JUNIOR (1991), the aleyrodids can get two or six generations per year. Whitefly populations can reproduce continuously with appropriate temperature and photoperiod conditions.

MOUND; HALSEY (1978) consider that the study of aleyrodids, since the early $20^{\text {th }}$ century, presented a large number of changes, such as the redefinitions of subfamily, genus and species, even for synonyms, and even nowadays this situation can be found. In the 20s, BONDAR $(1923 ; 1928)$ and HEMPEL (1922a; 1922b) described some species that were later characterized by synonymy.

Only from 2011, some studies have shown new hosts and geographic expansion of whiteflies in Brazil (TRINDADE et al., 2011; TRINDADE; LIMA, 2012; TRINDADE et al., 2012). Considering the geographic expansion, these studies included assessments in the Atlantic forest, not before explored as a learning environment for this group of insects.

These studies are relevant as they provide subsidies for the elucidation of the whitefly colonization process in new environments. In this context, REITZ (2007) reports that invasive species, such as aleyrodids, can cause ecological damage, often displacing native or endemic species and promoting modification in environments with their own characteristics. The author also observed that such exotic organisms eventually become established members of these environments and begin spreading into new areas. In addition to the ecological concerns, these studies are particularly important for providing elements to understand the colonization dynamics of aleyrodids in new environments, since among the representative of this group there are relevant agricultural pests.

Thus, forest fragments can be considered as the main new environments to be colonized by the aleyrodids. Given the effects of anthropization, such as the edge effects, the vegetation starts to suffer the consequences of this situation and thus provides conditions for attracting insects, since environments under environmental disturbance are favorable to attracting phytophagous.
Given that, this study aimed to assess and register the occurrence of individuals of the family Aleyrodidae in three Atlantic forest fragments in the state of Rio de Janeiro, Brazil, also proposing a taxonomic key for the genera indicated in this survey.

\section{MATERIALS AND METHODS}

For this study, it was collected monthly, from May 2013 to May 2014, aleyrodids in three Atlantic forest fragments in different states of conservation: Mangaratiba, in Sahy district; Nova Friburgo; and Rio de Janeiro (Grajaú Forest Reserve).

The sampled area in each fragment had 1 hectare delimited using the software Google Earth. The information was inserted into a global positioning system (GPS) Garmin, and the area was randomly demarcated in the field with the use of measuring tape and adhesive tapes. In each area, two cecropias were selected for monitoring, being collected randomly five leaves of each tree per month. The presence of whiteflies during the 12 months of the survey was recorded in the other plants that occurred in the defined area. Once the presence of the whitefly was recorded, the host was taxonomically identified, as well as the whitefly that occurred. The total quantification of the insects occurred by the random and monthly collection of five leaves of these plants.

A brief characterization of these environments can be found as follows.

- Mangaratiba’s fragment (UTM (23K) $601786.00 \mathrm{~m} \mathrm{E}$, 7462842.83 m S; 2256'21.93” S, 4400'26.15” W): this area is about $344 \mathrm{~m}$ from the sea, with slope over $45^{\circ}$, dense secondary vegetation, and developed without planning or forest maintenance;

- Nova Friburgo's fragment (UTM (23K) $748267.53 \mathrm{~m} \mathrm{E}$, $7533884.31 \mathrm{~m} \mathrm{~S} ; 22^{\circ} 16^{\prime} 58.20^{\prime \prime}$ S, $\left.42^{\circ} 35^{\prime} 25.54^{\prime \prime} \mathrm{W}\right)$ : this area is about $180 \mathrm{~m}$ from a road, with slope of $45^{\circ}$, dense vegetation, and developed without planning or forest maintenance. It has tabebuias, tibouchinas, cecropias, angicos, bromeliads, and many shrubs typical of the Atlantic forest. After the fragment demarcation, which had signs of occasional traffic of people, probably hunters and plant collectors, the observations were carried out;

- Rio de Janeiro's fragment (UTM (23K) $677950.64 \mathrm{~m} \mathrm{E}$, $7464674.06 \mathrm{~m} \mathrm{~S} ; 22^{\circ} 54^{\prime} 59.51^{\prime \prime}$ S, $\left.43^{\circ} 15^{\prime} 53.35^{\prime \prime} \mathrm{W}\right)$ : this area is located about $180 \mathrm{~m}$ from the Grajaú-Jacarepaguá road, bordering the community Morro do Encontro, which was developed on the Grajaú Forest Reserve. It has slope lower than $45^{\circ}$, vegetation fragment strongly anthropized and numerous exotic species that have been cultivated or not by residents of the nearby community, which uses the space for hiking and hunting of wild animals, especially birds. Throughout the existence of this forest reserve, whose 
symbol is a rock known as Pico do Perdido do Grajaú, accidental fires or not have happened in all areas of this urban forest; the studied fragment had the characteristic of being burned almost every year. In the trees and shrubs, with the exception of the cecropias, in which whiteflies were found, it was collected periodically and randomly ten leaves located at the lower part of the canopy; in the underbrush, it was collected randomly ten leaves.

The survey consisted of the inspection and collection of individuals directly on the plants inserted in the fragment. Once detected the presence of aleyrodids, the hosts were marked and monitored monthly by checking the lower part of the canopy. The collected leaves were placed in paper envelopes and sent to the laboratory of the Universidade Federal Rural do Rio de Janeiro (UFRRJ) Technical College for the puparia identification ( $4^{\text {th }}$ instar nymphs) and, when necessary, sent to the Botany Department of the UFRRJ for later herborization and identification.

When detected whiteflies, the $4^{\text {th }}$ instar nymphs (puparia) were removed from the foliar limb with the use of insect pushpin and, after quantification, fixed between slides and coverslips, using the mounting mediums Hoyer's and/or Canada balsam. The slides were properly labeled with information about the host, place, date and collector, and then taken to an oven at $37^{\circ} \mathrm{C}$ for a minimum period of 48 hours for removal of air bubbles and drying.

In order to determine the species of whiteflies, it was used stereoscopic microscopes Wild M 5 and Olympus SZ 40 and microscopes Wild M 20 and Olympus BX 41. For the taxonomic identification, the studies of EVANS (2007), HEMPEL (1922a; 1922b), BONDAR (1923; 1928), COSTA LIMA (1928), MARTIN (2004; 2008) and TRINDADE et al. (2012) were consulted.

The terminology used in the description or discussion related to the species considered in this study follows those detailed by RUSSELL (1965), GILL (1990) and MARTIN (2008).

For data analysis, it was generated a table listing the hosts, whitefly species and number of puparia, counted during the collection period.

Additionally, for the whitefly Aleuropleurocelus cecropiae, it was elaborated a seasonality graph of the $4^{\text {th }}$ instar nymphs (puparia) in the three fragments. This analysis was performed because $A$. cecropiae has been the only whitefly that met the criteria of having host occurring in the three assessed areas. Due to this characteristic, it was also adopted the analysis of variance of the average number of $4^{\text {th }}$ instar nymphs. For this, the normality of data was conducted by the Lilliefors test, with subsequent use of the Kruskal-Wallis test at $5 \%$ of significance. The significant differences between the mean ranks were detected by the StudentNewman-Keuls test ( $5 \%$ of significance) and highlighted the true mean. The data were processed using the software BioStat 5.0.

\section{RESULTS AND DISCUSSION}

It was collected 1,212 puparia, of which 105 in Friburgo, 58 in Mangaratiba and 1,049 in Rio de Janeiro. These individuals are from five genera and seven species of whitefly, registered occurring in nine hosts (Table 1). It was only observed the subfamily Aleurodinae, which has the largest number of genera among this group of insects (EVANS, 2008). The genera are: Aleuropleurocelus (Drews \& Sampson, 1956), Aleurothrixus (QUAINTANCE; BAKER, 1914), Aleurotrachelus (QUAINTANCE; BAKER, 1914), Bemisia (Gennadius, 1889) and Minutaleyrodes (Singh, 1931). As a contribution to the identification of these individuals, it is suggested a dichotomous key of these genera.

Regarding to the predation, it was observed Harmonia axyridis (Pallas, 1773) (Coleoptera: Coccinellidae) preying on Bemisia tabaci, and Chrysoperla externa (Hagen, 1861) (Neuroptera: Chrysopidae) preying on nymphs of B. tabaci and Aleurothrixus aepim.

According to EVANS (2008), aleyrodids at $4^{\text {th }}$ instar nymphs are recognized for not having compound pores (with simple pores usually absent), leg apexes showing circular discs, and short lingula not covering the vasiform orifice, with only a pair of setae close of it.

It was registered a wide range of hosts for Aleurothrixus floccosus, around six host plant species, as well as a greater amount of $4^{\text {th }}$ instar nymphs collected. In these observations this whitefly on Handroanthus ochraceus and Mangifera indica was registered for the first time. In its turn, B. tabaci has occurred on three hosts and observed for the first time on Commelina benghalensis and Caesalpinia pluviosa. The aleyrodid Minutaleyrodes minuta also had its first register being hosted by Syzygium cumini (Table 1).

According to the taxonomic characters, the morphospecies sp. on Psychotria nuda is part of the genus Aleurothrixus, in accordance to the dichotomous key, and may possibly represent a new species, being considered for this hypothesis the morphological differences in the abdominal segment, vasiform orifice and lingula when compared to the other known species of this genus.

The whitefly B. tabaci is one of the world's major insect pests and it is associated with 600 hosts and with the transmission of several viruses (GALLO et al., 2002; REITZ, 2007; LIU et al., 2012). In this work, it was observed great ability of this species to be hosted by underbrush, such as $C$. benghalensis (spiderwort), as well as by the arboreal species $C$. pluviosa (sibipiruna). According to GALLO et al. (2002), B. tabaci is widespread in Brazil. RIIS; NACHMAN (2006) consider that the whiteflies B. tabaci and Trialeurodes vaporariorum (Westwood, 1856) act only on vegetable crops, especially on the families Curcubitaceae, Leguminosae and Solanaceae. However, this study observed the capacity of $B$. tabaci be hosted by hosts with different habits and sizes; the same probably would happen to T. vaporariorum. Thus, such non-horticultural hosts may 
be a source of spread of whiteflies even in forest fragments if there is no phytosanitary control. This condition may probably be installed in Rio de Janeiro's fragment.

In the Atlantic forest fragments, where samples were taken, small amounts of whitefly species were registered, especially those considered as economically important, except in the Grajaú Forest Reserve. The register of the occurrence of whiteflies was more numerous and diverse at the community Morro do Encontro, which is the most anthropized portion of the Grajaú Forest Reserve.

The factors that could possibly have contributed to the worsening of this condition in the Grajaú Forest Reserve were the reduction of predators and a favoring of microclimate conditions such as increased temperature and decreased humidity, which are related to the spread of whiteflies, in addition to possible successive introductions of exotic plant genetic load, such as fruit trees. In this fragment, located next to the community Morro do Encontro, only a deteriorated wall separates the forest from the residential area and many residents pass freely through the site. Moreover, the area has a history of fires that spread throughout the Reserve, contributing to the modification of the local flora.

Because of the better ecological structure of the forest fragments in Mangaratiba and Friburgo when compared to the Rio de Janeiro's fragment, it was considered that the more preserved the habitat is, the fewer aleyrodid species are registered, which were not considered of economic importance.
Considering that the data analysis, it is suggested that A. cecropiae has characteristics that indicate its potential for bioindication. Its occurrence responded consistently to the ecosystem anthropization, being therefore registered a lower average number of individuals in Mangaratiba and Nova Friburgo when compared to Rio de Janeiro, which is the most ecologically disturbed fragment in relation to the others, although the significant difference has been observed only in the comparison conducted with the values registered in Nova Friburgo (Table 2). In addition, the whitefly $A$. cecropiae has as host Cecropia hololeuca, a native plant species that occurs in secondary forest environments, facilitating sampling in future monitoring.

Table 2. Mean number ( \pm standard deviation) and maximum and minimum room of individuals instar (pupae) of Aleuropleurocelus cecropiae collected in Cecropia hololeuca occurring sheets in three forest fragments in the state of Rio de Janeiro, Brazil, in May 2013 to May 2014.

\begin{tabular}{lccc}
\multirow{2}{*}{ Area } & $\begin{array}{c}\text { Number } \\
\text { average }\end{array}$ & \multicolumn{2}{c}{ Individuals number } \\
\cline { 3 - 4 } Mangaratiba & $4,46 \pm 3,12 \mathrm{a}$ & 12 & 0 \\
\hline Nova Friburgo & $1,54 \pm 2,44 \mathrm{~b}$ & 6 & 0 \\
\hline Rio de Janeiro & $6,69 \pm 3,99 \mathrm{a}$ & 14 & 0 \\
\hline
\end{tabular}

Means followed by different letters in lines, they are statistically different (Student-Newman-Keuls test, $5 \%$ of significance).

Table 1. Host, whitefly species and number of pupae collected in three forest fragments located in the cities of Friburgo, Mangaratiba and Rio de Janeiro, Rio de Janeiro, Brazil, from May 2013 to May 2014.

\begin{tabular}{|c|c|c|c|c|c|c|}
\hline \multirow{2}{*}{ Host } & \multicolumn{2}{|l|}{ Friburgo } & \multicolumn{2}{|c|}{ Mangaratiba } & \multicolumn{2}{|c|}{ Rio de Janeiro } \\
\hline & Whitefly & n & Whitefly & N. & Whitefly & $\mathbf{n}$ \\
\hline Cecropia hololeuca & Aleuropleurocelus cecropiae & 20 & A. cecropiae & 58 & A. cecropiae & 87 \\
\hline Handroanthus ochraceus & Aleurothrixus floccosus & 64 & N.H.R. & --- & N.H.R. & --- \\
\hline Psychotria nuda & Morphospecies sp. & 21 & N.H.R. & --- & N.H.R. & --- \\
\hline \multirow{3}{*}{ Syzygium cumini } & \multirow{3}{*}{ N.H.R. } & \multirow{3}{*}{---} & \multirow{3}{*}{ N.H.R. } & \multirow{3}{*}{---} & A. floccosus & 136 \\
\hline & & & & & Austrogomphus atratus & 25 \\
\hline & & & & & Minutaleyrodes minuta & 31 \\
\hline Mimosa caesalpiniifolia & N.H.R. & --- & N.H.R. & --- & A. floccosus & 96 \\
\hline \multirow{3}{*}{ Psidium guajava } & \multirow{3}{*}{ N.H.R. } & \multirow{3}{*}{---} & \multirow{3}{*}{ N.H.R. } & \multirow{3}{*}{--- } & A. atratus & 49 \\
\hline & & & & & Bemisia tabaci & 34 \\
\hline & & & & & Aleurothrixus aepim & 190 \\
\hline \multirow{2}{*}{ Schinus terebinthifolius } & \multirow{2}{*}{ N.H.R. } & \multirow{2}{*}{---} & \multirow{2}{*}{ N.H.R. } & \multirow{2}{*}{---} & A. floccosus & 26 \\
\hline & & & & & A. atratus & 74 \\
\hline Mangifera indica & N.H.R. & --- & N.H.R. & --- & A. floccosus & 4 \\
\hline Commelina benghalensis & N.H.R. & --- & N.H.R. & --- & B. tabaci & 287 \\
\hline Caesalpinia pluviosa & N.H.R. & --- & N.H.R. & --- & B. tabaci & 10 \\
\hline Total & & 105 & & 58 & & 1,049 \\
\hline
\end{tabular}

N.H.R.: no host register. 
Furthermore, $A$. cecropiae in addition to responding to changes in biota, such as the vegetation stress, also has demonstrated its occurrence influenced by abiotic issues. In this sense, it was observed that dry months provided conditions for the increase in population, with population peaks occurring during this period (Fig. 1).

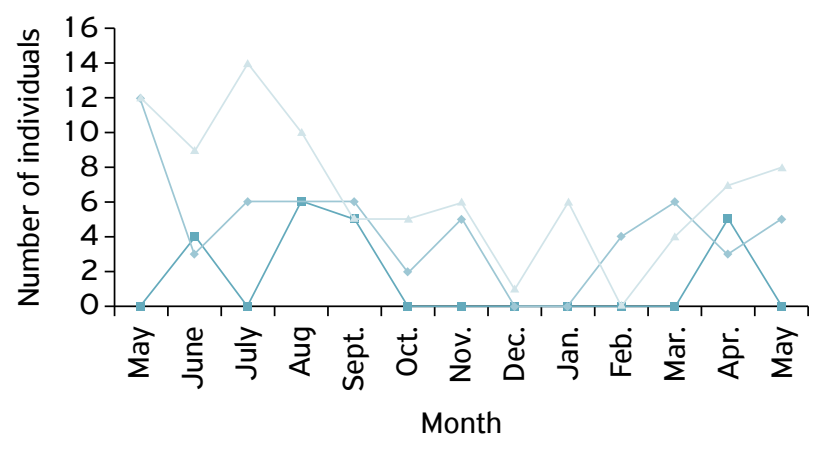

- Mangaratiba - Nova Friburgo $\rightarrow$ Rio de Janeiro

Figure 1. Seasonality room individuals instar (pupae) of Aleuropleurocelus cecropiae collected in Cecropia hololeuca occurring sheets in three forest fragments in the state of Rio de Janeiro, Brazil, from May 2013 to May 2014.

\section{CONCLUSION}

As a hypothesis, this study suggests that whitefly species considered pests will spread increasingly in the Grajaú Forest Reserve, which is a component of the Tijuca Forest, settling on new hosts and thus providing other dispersion points, given the advanced state of anthropization of this forest fragment. For this reason, it is appropriate to research new colonization process environments by the family Aleyrodidae, especially in forest fragments, being possible to provide information for pest control solutions, in addition to ecological knowledge of this insect group.

About these concepts, REITZ (2007) considers that the invasions offer opportunity for ecological experimentation, but unfortunately it can cause enormous environmental and economic costs. This condition was registered in this survey, especially in the Rio de Janeiro's fragment, where the number of hosts is significant and all whitefly species present economic importance, notably A. floccosus and B. tabaci. This author also observed that the displacement of invasive species could cause the extinction of local species, which are more susceptible to changes in environmental conditions, a fact not observed along the collects since the whiteflies were already present in the areas.

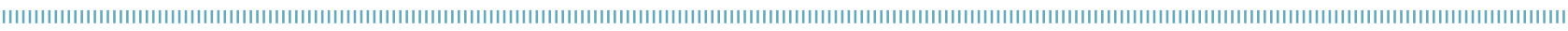
REFERENCES

BONDAR, G. Aleyrodídeos do Brasil: catálogo descriptivo dos Hemípteros-Homópteros da família dos Aleyrodídeos, insectos parasitas das plantas, encontrados no Brasil. Salvador: Secretaria da Agricultura, Indústria e Obras Públicas do Estado da Bahia, 1923. 183p. (Boletim do Laboratório de Pathologia Vegetal do estado da Bahia).

BONDAR, G. Aleyrodideos do Brazil (2a contribuição). Salvador: Secretaria da Agricultura, Indústria e Obras Públicas do Estado da Bahia, 1928. 37p. (Boletim do Laboratório de Pathologia Vegetal do estado da Bahia, 5).

BYRNE, D.N; BELLOWS JUNIOR, T.S. Whitefly biology. Annual Review of Entomology, Palo Alto, v.36, p.431-457, 1991. https:// doi.org/10.1 146/annurev.en.36.010191.002243

COSTA LIMA, A.M. Contribuição ao estudo dos aleyrodideos da subfamília Aleurodicinae. Memórias do Instituto Oswaldo Cruz, Rio de Janeiro, v.4, p.128-140, 1928.

COSTA LIMA, A.M. Superfamília Aleyrodoidea. In: COSTA LIMA, A.M. Insetos do Brasil. Rio de Janeiro: Escola Nacional de Agronomia, 1942. t. 3. p. 179-191. (Série Didática, 4).

EVANS, G. The whiteflies (Hemiptera: Aleyrodidae) of the world and their host plants and natural enemies. Riverdale Park: United States, Department of Agriculture/Animal Plant Health Inspection Service, 2007. 708p.
GALLO, D.; NAKANO, O.; SILVEIRA NETO, S.; CARVALHO, R.P.L.; BAPTISTA, G.C.; BERTI FILHO, E.; PARRA, J.R.P.; ZUCCHI, R.A.; ALVES, S.B.; VENDRAMIN, J.D.; MARCHINI, L.C.; LOPES, J.R.S.; OMOTO, C. Entomologia agrícola. Piracicaba: FEALQ, 2002. 920p. (Biblioteca de Ciências Agrárias Luiz de Queiroz, 10).

GILL, R.J. The morphology of whiteflies. In: GERLING, G.D. (Ed.). Whiteflies: their bionomics, pest status and management. Newcastle: Intercept, 1990. p.13-46.

GULLAN, P.J.; CRANSTON, O.S. Os insetos: um resumo de entomologia. In: Biologia Reprodutiva de Insetos e Plantas. São Paulo: Roca, 2007. p.246-262.

HEMPEL, A. Algumas espécies novas de Hemipteros da família Aleyrodidae. Notas Preliminares Editadas pela Redacção do Museu Paulista, v.2, p.3-10, 1922a.

HEMPEL, A. Hemipteros novos ou pouco conhecidos da familia Aleyrodidae. Revista do Museu Paulista, v.13, p.1121-1191, $1922 b$.

LIU, S.S.; COLVIN, J.; DE BARRO, P. Species concepts as applied to the whitefly Bemisia tabaci systematics: how many species are there? Journal of Integrative Agriculture, v. 11 , n.2, p.176-186, 2012. https://doi.org/10.1016/ S2095-3119(12)60002-1 
MARTIN, J.H. The whiteflies of Belize (Hemiptera: Aleyrodidae) Part 1 - introduction and account of the subfamily Aleurodicinae Quaintance \& Baker. Zootaxa, v.681, n.1, p.1-1 19, 2004. http:// dx.doi.org/10.1 1646/zootaxa.681.1.1

MARTIN, J.H. A revision of Aleurodicus Douglas (Sternorrhyncha, Aleyrodidae), with two new genera proposed for palaeotropical natives and an identification guide to world genera of Aleurodicinae. Zootaxa 1835, p.1-100, 2008.

MOUND, L.A; HALSEY, S.H. Whitefly of the world: A systematic catalogue of the Aleyrodidae (Homoptera) with host plant and natural enemy data. Chichester: J. Wiley, 1978. 358p.

QUAINTANCE, A.L; BAKER, A.C. Classification of the Aleyrodidae Part I. Washington: Bureau of Entomology, 1914. p.1-93. (USDA Technical Series n. 27).

REITZ, S.R. Invasion of the whiteflies. Science, v.318, n. 5857 p.1733-1734, 2007.https://doi.org/10.1126/science.1152124

RIIS, L.; NACHMAN, G. Migration, trapping and local dynamics of whiteflies (Homoptera: Aleyrodidae). Agricultural and
Forest Entomology, v.8, n.3, p.233-241, 2006. https://doi. org/10.1111/j.1461-9563.2006.00302.x

RUSSELL, L.M. A new species of Aleurodicus Douglas and two close relatives (Homoptera: Aleyrodidae). Florida Entomologist, v.48, n.1, p.47-55, 1965. https://doi. org/10.2307/3493523

TRINDADE, T.D.; LIMA, A.F.; RACCA FILHO, F. Espécies de Paraleyrodes Quaintance (Hemiptera:Aleyrodidae) no estado do Rio de Janeiro, Brasil. Entomotropica, v.26, n.2, p.69-77, 2011.

TRINDADE, T.D.; LIMA, A.F. Predação de espécies de moscas brancas (Hemiptera: Aleyrodidae) por Chrysoperla Steinmann (Neuroptera: Chrysopidae) no estado do Rio de Janeiro, Brasil. Entomotropica, v.27, n.2, p.71-75, 2012.

TRINDADE, T.D.; RACCA FILHO, F.; LIMA, A.F. Aleurodicus Douglas (Hemiptera: Aleyrodidae, Aleurodicinae) no estado do Rio de Janeiro e primeiro registro de Aleurodicus trinidadensis Quaintance \& Baker para o Brasil. Entomotropica, v.27, n.2, p.57-70, 2012. 